\title{
Evaluation of an Enzymatic Two Point Determination of the Glucose Concentration in 40 1 Blood Samples with a GEMSAEC Analyzer
}

\author{
By R. HAECKEL \\ Technical Assistance: K. Dettmer and W. Pieper \\ Institut für Klinische Chemie (Geschäftsfübrender Direktor: Prof. Dr. Dr. J. Biittner) \\ Medizinische Hocbschule Hannover
}

(Eingegangen am 21. März 1973)

Herrn Professor Dr. Dr. E. Scbütte anläßlich seines 65. Geburtstages genvidmet

\begin{abstract}
A 2 point procedure for the enzymatic determination of glucose concentrations, using hexokinase and glucosc-6-phosphate dehydrogenase, was evaluated with a GEMSAEC analyzer. The proposed method appears to be very useful in clinical chemistry for several reasons: it has a high reliability and docs not need a deproteinisation step; with the exception of glucose-6-phosphate, no other substance has been found so far that causes significant interference; a single analysis takes 7.5 minutes; drift and interaction effects can be neglected. Capillary blood, serum, cerebrospinal fluid or urine can be analyzed without the determination of a sample blank value. Blood is collected with $40 \mu \mathrm{l}$ glass capillaries, then transferred into a sodium chloride solution containing maleimide to avoid glycolysis. Under these conditions blood samples can be transported by a pneumatic tube system and stored for several days.
\end{abstract}

Ein Zweipunkt-Meßverfahren wurde zur enzymatischen Bestimmung der Glucosekonzentration mit Hexokinase und Glucose-6-phosphatdehydrogenase an einem GEMSAEC Analysenautomaten entwickelt und auf seine Zuverlässigkeit untersucht. Die vorgeschlagene Methode ist aus mehreren Gründen für die Klinische Chemie besonders geeignet: sie hat eine große Zuverlässigkeit und benötigt keinen Enteiweißungsschritt; bisher wurden mit Ausnahme von Glucose-6-phosphat keine signifikanten Interferenzen gefunden; das Ergebnis einer Einzelbestimmung liegt nach 7,5 Minuten vor; Drift- und Verschleppungseffekte können vernachlässigt werden. Kapillarblut, Serum, Liquor oder Urin können ohne Mitführen eines Probenleerwertes analysiert werden. Blutproben werden mit $40 \mu l$ Glaskapillaren dosiert und in Vorlagen mit einer Lösung von Natriumchlorid und Maleimid zur Glycolysehemmung ausgeschüttelt. Unter diesen Bedingungen können die Proben per Rohrpost transportiert und einige Tage aufbewahrt werden.

The enzymatic determination of the glucose concentration with hexokinase and glucose-6-phosphate dehydrogenase (Hexokinase method) is now widely used for clinical purposes. Automatic procedures mostly require the separation of serum proteins before the reaction can be started $(1,2)$, or the determination of a sample blank value. This disadvantage is overcome with analyzers which are able to take at least 2 readings during the reaction (14).

A GEMSAEC analyzer (3-6) was used to evaluate such a two-point method for the determination of the glucose concentration based on a commercially available test combination.

Blood samples were taken from finger tips with heparinized glass capillaries as recently described $(2,7)$ and transferred into sodium chloride solution $(500 \mu \mathrm{l})$ containing maleimide to avoid glycolysis (8).

\section{Materials}

The solutions of the reaction mixture were taken from the Biochemica test combination No. 15931 of C. F. Boehringer GmbH (D-68 Mannheim); bovine albumin (dried, purest) and precision control sera were purchased from Behringwerke AG (D-355 Marburg), glucose-6-phosphate from C. F. Boehringer GmbH (No. 15307), maleimide from Dr. Th. Schuchard (D-8 Munich), Monitrol from Merz and Dade (D-8 Munich), all other chemicals p. a. from E. Merck AG (D-61 Darmstadt), reaction cups (No. 39/10) with their corresponding caps (No. 98) and heparinized monovettes (No. 750) from W. Sarstedt (D-5223 Nümbrecht), and heparinized glass capillaries from W. Vogel (D-63 Gießen).

\section{Solutions}

1. Sodium chloride solution: $9 \mathrm{~g} \mathrm{NaCl}$ (Merck No. 6404), $200 \mathrm{mg}$ maleimide (Schuchardt Nr. MA 084) + bidist. $\mathrm{H}_{2} \mathrm{O}$ to $1000 \mathrm{ml}$. This solution was stable for at least 4 weeks at room temperature.

2. Glucose standard, $10 \mathrm{mmol} / \mathrm{l}: 450.4 \mathrm{mg}$ dried glucose (Merck No. 8337), $250 \mathrm{mg}$ sodium azide (Merck No. 6688) + bidist. $\mathrm{H}_{2} \mathrm{O}$ to $250 \mathrm{ml}$.

3. Glucose working standard: $4.0 \mathrm{ml}$ solution (2) $+50.0 \mathrm{ml}$ solution (1). This solution was stable for at least 1 month at $4^{\circ} \mathrm{C}$ and was added directly to the Rotoloader cups.

4. Potassium dichromate (Merck No. 4864), was dissolved in $0.01 \mathrm{~mol} / 1 \mathrm{H}_{2} \mathrm{SO}_{4}$ (Merck No. 9982) to give an absorbance of approx. 0.455 at $340 \mathrm{~nm}(4.5 \mathrm{mg} / \mathrm{l})$.

5. Reaction mixture: Solutions $1-4$ were taken from the Biochemica test combination; the volume of solution 2-4 were chosen to optimize the concentration of enzymes and cofactors (Fig. $1 \mathrm{a}-\mathrm{c}$ ). The concentrations of the enzyme suspension were not altered because these investigations ought to be based on the commercially available test combination. The slight downward deflection of the saturation curve in Figure $1 \mathrm{c}$ at higher enzyme concentrations was probably caused by the concomitant increase of $\mathrm{NH}_{4}$ ions.
Solution 1
$89 \mathrm{ml}$
$2.74 \mathrm{mmol} / 1, \mathrm{pH}=7.5$
Solution $2 \quad 5 \mathrm{ml} \quad$ NADP $0.46 \mathrm{mmol} / \mathrm{l}$
Solution $3 \quad 5 \mathrm{ml} \quad$ ATP $0.62 \mathrm{mmol} / \mathrm{l}$
Solution $4 \quad 1 \mathrm{ml} \quad$ Hexokinase $7.69 \mathrm{mg} / \mathrm{l}$
(Enzyme suspension) Glucosc-6-phosphat-dehydrogenasc $7.69 \mathrm{mg} / \mathrm{l}$.

End concentration of assay:

This reaction mixture was stable at least $24 \mathrm{~h}$ at $4^{\circ} \mathrm{C}$ or $7 \mathrm{~h}$ at room temperature. 

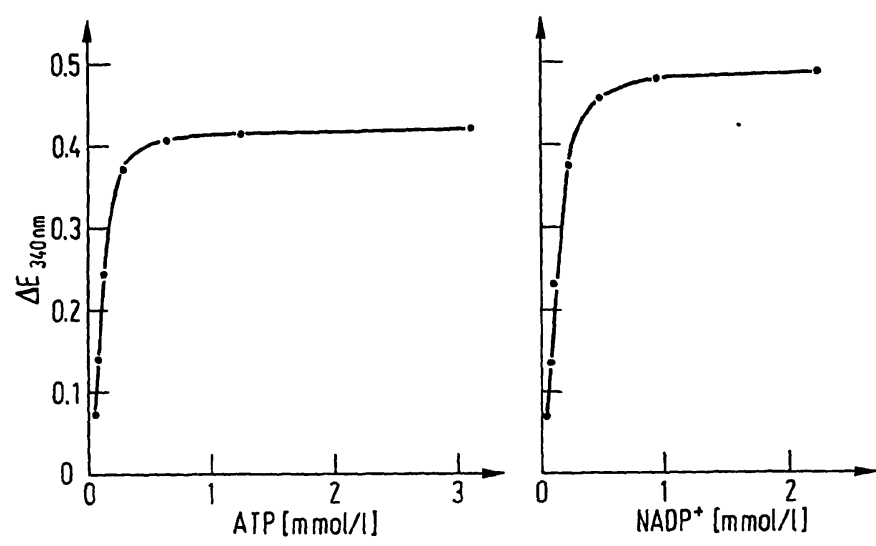

Instrumentation

Electro Nucleonics Inc. (USA, Fairfield 07006): GEMSAEC analyzer with control module (Serial No. 2113) and Rotoloader (Serial No. 008) with Micromedic dispensers (Serial No. 557 for sample + diluent, and serial No. 609 for reagent). Eppendorf Gerätebau GmbH (D-2 Hamburg): Microcentrifuge 3200, micropipettes, dispenser 5231 .

\section{Methods $\quad \therefore$}

Blood samples $(40 \mu \mathrm{l})$ were taken with heparinized glass capillaries after skin puncture. The filled capillaries were introduced into an Eppendorf reaction cup with $500 \mu \mathrm{l}$ saline solution which contained maleimide to delay glycolysis (Tab. 1). After the cup was closed and shaken it could be either stored at $4^{\circ} \mathrm{C}$ or transported by a pneumatic tube system. The reaction cups were filled up to 4 weeks prior to use. During this time the fluid loss did not exceed $1 \%$ if the cups were carefully closed and stored at room temperature.

Tab. 1

The stability of the glucose concentration ( $\mathrm{mmol} / \mathrm{l}$ ) in $\mathbf{4 0} \mu \mathrm{l}$ blood samples taken up in $500 \mu \mathrm{l}$ sodium chloride $(9 \mathrm{~g} / \mathrm{l})$. Blood was aspirated in monovettes containing heparinized beads, distributed into various reaction cups filled with $\mathrm{NaCl}$ solution and stored as indicated below. Each value is a mean of 2 determinations.

\begin{tabular}{lccccc}
\hline Storage, days & 0 & 1 & 2 & 3 & 4 \\
\hline $\mathrm{NaCl}+$ Maleimide & & & & & \\
$(200 \mathrm{mg} / \mathrm{l})$ stored at $4^{\circ} \mathrm{C}$ & 4.7 & 4.7 & 4.7 & 4.7 & 4.7 \\
$\mathrm{NaCl}+$ Maleimide & & & & & \\
$(200 \mathrm{mg} / \mathrm{l})$ stored at $20^{\circ} \mathrm{C}$ & 4.7 & 4.7 & 4.8 & 4.8 & 4.8 \\
$\mathrm{NaCl}$ stored at $4^{\circ} \mathrm{C}$ & 4.6 & 3.4 & 2.5 & 1.8 & 1.2 \\
$\mathrm{NaCl}$ stored at $20^{\circ} \mathrm{C}$ & 4.6 & 2.9 & 2.0 & 1.2 & 0.6 \\
\hline
\end{tabular}

Tab. 2

Summary of the methodology of the glucose determination with the GEMSAEC analyzer

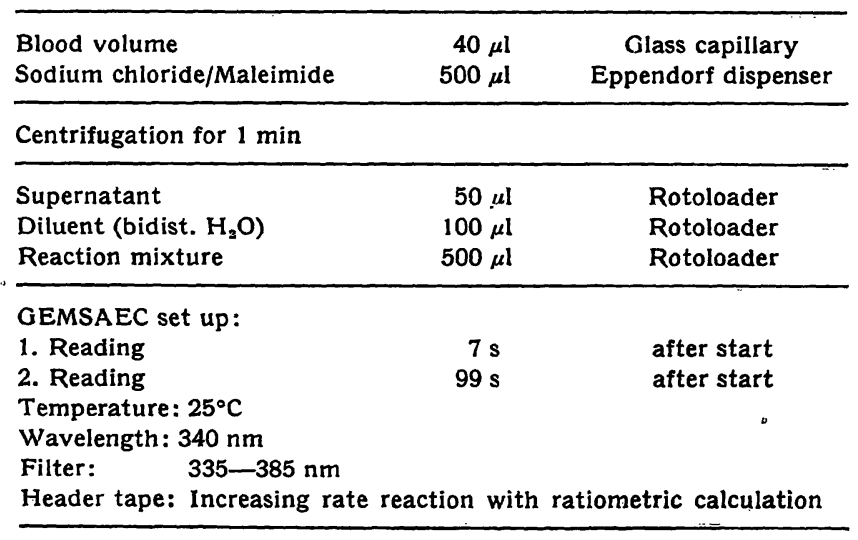

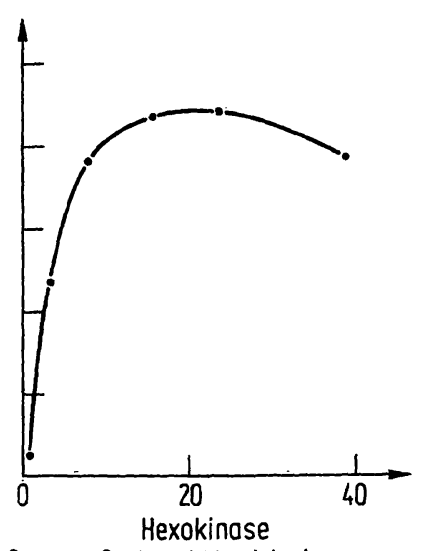

+Glucose-6-phosphate dehydrogenase [mg/l]

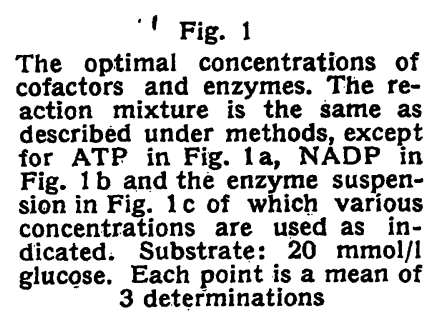

Prior to the analysis, the reaction cup was centrifuged for $1 \mathrm{~min}$ in an Eppendorf microcentrifuge without removing the glass capillary. The supernatant could either be transferred to a Rotoloader or directly to a cuvette-rotor using a $50 \mu 1$ Eppendorf pipette.

The protocol for the Rotoloader and the GEMSAEC analyzer are summarized in Table 2 . If $20 \mu \mathrm{l}$ glass capillaries are used, the sample volume must be increased to $100 \mu \mathrm{l}$. The analyzer automatically takes 8 readings (during approx. 1 second) for the first and for the second point. The difference of both mean values is printed out together with the final result (in $\mathrm{mmol} / \mathrm{l}$ ).

\section{Sequence of samples}

Cuvette 1 : standard

Cuvette 2 : control serum

Cuvette 3-15: unknown samples

Cuvette 16 : control serum or unknown sample.

The recovery of glucose added to various serum samples was calculated from the results of the following assays:

1. $9.0 \mathrm{ml}$ bidist. $\mathrm{H}_{2} \mathrm{O}+1.0 \mathrm{ml}$ glucose solution $(100 \mathrm{mmol} / \mathrm{l})$;

2. $9.0 \mathrm{ml}$ pooled serum +1.0 glucose solution $(100 \mathrm{mmol} / \mathrm{l})$;

3. $9.0 \mathrm{ml}$ pooled serum $+1.0 \mathrm{ml}$ bidist. $\mathrm{H}_{2} \mathrm{O}$.

The interaction from low to high concentrations $\left(Q_{1}\right)$ and from high to low concentrations $\left(Q_{2}\right)$ was determined as recently reported (10) and expressed as the percent interaction coefficient: $\mathrm{Q}=100 \times \mathrm{q}$. (For the explanation of $\mathrm{q}$ see $9,10,11$ ).

The detection limit was determined by using bidist. $\mathrm{H}_{2} \mathrm{O}$ as a sample during 20 runs with the two-point procedure: the threefold standard deviation of the mean value is a measure for the detection limit according to KAISER (12).

\section{Statistical analysis}

For the determination of the precision 2 identical serum samples $\left(x_{a}, x_{b}\right)$ are serially analyzed. The precision-within-series $\left(C V_{s}=\frac{100 \cdot \bar{x})}{s}\right.$ is calculated from the $x_{a}$ and $x_{b}$ values:

$$
\text { (1) } \bar{x}=\frac{\sum_{i=1}^{n}\left(x_{a 1}+x_{b 1}\right)}{2 m} ; s=\sqrt{\frac{\sum_{i=1}^{n}\left(x_{a 1}-x_{b i}\right)^{2}}{2 m}} .
$$

The precision-from-day-to-day is calculated from the $x_{0}$ - (or the $\mathrm{x}_{\mathbf{b}}-$ ) values:

$$
\text { (2) } \bar{x}_{\mathrm{a}}=\frac{\sum_{\mathrm{i}=1}^{n} \mathrm{x}_{\mathrm{ai}}}{\mathrm{n}} ; s=\sqrt{\frac{\sum_{i=1}^{n}\left(x_{\mathrm{ai}}-\overline{\mathrm{x}}_{\mathrm{a}}\right)^{2}}{n-1}} \text {. }
$$




\section{Results}

\section{Preparation of samples}

During these investigations disposable $40 \mu 1$ glass capillaries were used for blood sampling. Their precision was tested by weighing bidist. $\mathrm{H}_{2} \mathrm{O}: 39.76 \pm$ $0.26 \mu l \quad(n=32)$. The coefficient of variation was $0.6 \%$ (room temperature was taken into account). Recently it was reported that even $20 \mu$ l capillaries can be used with sufficient precision for clinical purposes $(2,7)$.

\section{Precision}

The overall precision of the optical and the read-out system was determined by dichromate solutions of varying concentrations (Fig. 2). The data obtained agreed well with those reported by MACLIN (13). The precision of the Rotoloader and the overall precision of the glucose determination are summarized in Table 3 and 4. The precision from-day-to-day (Tab. 4b) was

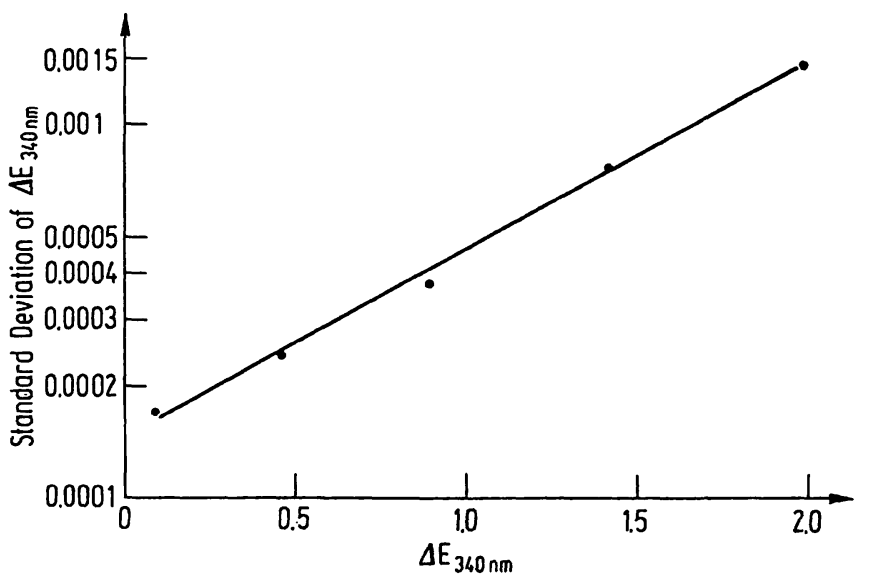

Fig. 2

The overall . precision of the optical and the read-out system of the GEMSAEC analyzer. The rotor was filled with $500 \mu 1$ samples of dichromate solution of varying concentrations. Wavelength: $340 \mathrm{n}$

1. reading: $5 \mathrm{~s}$; reading interval: $2 \mathrm{~s}$; number of readings: 26.

Tab. 3

Precision of the Rotoloader

\begin{tabular}{ccccc}
\hline Station & $\begin{array}{c}\text { Volume } \\
\text { setting }\end{array}$ & $\overline{\mathbf{x}}(\mu \mathrm{l})$ & $\mathrm{n}$ & $\mathrm{CV}(\%)$ \\
\hline Sample & 50 & 50.06 & $(16)$ & 0.43 \\
Diluent & $50+100$ & 134.30 & $(20)$ & 0.85 \\
Reagent & 500 & 500.00 & $(20)$ & 0.12 \\
\hline
\end{tabular}

Tab. 4 a

Precision within-series of the glucose determination with the GEMSAEC analyzer

\begin{tabular}{lcccc}
\hline Sample & $\begin{array}{c}\overline{\mathbf{x}} \\
(\mathrm{mmol} / \mathrm{l})\end{array}$ & $\begin{array}{c}\mathrm{s} \\
(\mathrm{mmol} / \mathrm{l})\end{array}$ & $\mathrm{n}$ & $\begin{array}{c}\mathrm{CV}_{2}^{*} \\
(\%)\end{array}$ \\
\hline I. Standard solution & 0.49 & 0.03 & $(14)$ & 5.5 \\
& 1.08 & 0.03 & $(14)$ & 3.0 \\
& 1.93 & 0.05 & $(14)$ & 2.5 \\
& 5.95 & 0.09 & $(14)$ & 1.5 \\
& 9.17 & 0.11 & $(14)$ & 1.2 \\
& 18.78 & 0.12 & $(14)$ & 0.6 \\
I1. Asid control serum & 6.04 & 0.07 & $(17)$ & 1.2 \\
(Charge No. 402 C) & & & &
\end{tabular}

*) Coefficient of variation
Tab. $4 \mathrm{~b}$

The precision from-day-to-day of the glucose determination with the GEMSAEC analyzer. Asid control serum (Charge No. 402 C) was analyzed on various days and referred to either 1 standard or to the mean value from several standards

\begin{tabular}{lccccc}
\hline Number of standards & 1 & 2 & 3 & 4 & 5 \\
\hline Mean value (mmol/1) & 6.01 & 5.97 & 5.97 & 5.95 & 5.98 \\
Standard deviation (mmol/l) & 0.14 & 0.15 & 0.15 & 0.15 & 0.16 \\
Coefficient of variation (\%) & 2.3 & 2.5 & 2.5 & 2.5 & 2.6 \\
Number of observations & 17 & 17 & 17 & 17 & 17 \\
\hline
\end{tabular}

not significantly improved if the results were referred to the mean of several standards instead to one standard value.

In most cases, analyzer runs are started only once a day after a series has been completed. These series usually consist of several segments (11). When a sequence of for instance 100 samples has to be analyzed with a GEMSAEC, it is a matter of definition to consider each run a series per se or just a segment of the whole series. For the purpose of comparing precision data from various analytic systems, it is suggested that each run be regarded as a series per se. Three types of precision can then be expected: 1 . the precision withinseries, 2. the precision between-series (during 1 day) and 3. the precision from-day-to-day.

The precision between-series (interbatch precision) must be differentiated from the precision from-day-today as shown in Table 5: 10 suceeding runs of the same control serum were analyzed for 8 days. The coefficient of variation (CV) was calculated for each run: $\overline{\mathrm{x}}_{\mathrm{Cv}}=$ $2.1 \%$. The precision between-series can be estimated from the first (or any other) value of each run during a day. The mean value of 8 days was $3.4 \%$. In the same way, the precision from-day-to-day can be calculated from the first (or any other) value of the first (or any other) run during the 8 days (Tab. 5).

Tab. 5

The 3 types of precision observed with a GEMSAEC analyzer using Behring control serum (Lot. No. 112). Each run yielded 12 values which were referred to 1 standard value $(10 \mathrm{mmol} / \mathrm{l})$, and was daily repeated ten times for 8 days. The mean value of all determinations was $5.2 \mathrm{mmol} / \mathrm{l}(\mathrm{n}=960)$

Type of precision

Coefficient of variation*) (\%)

\begin{tabular}{ll}
\hline 1. Precision within-series & $2.1(n=80)$ \\
II. Precision between-series & $3.4(n=96)$ \\
II. Precision from-day-to-day & $4.9(n=120)$
\end{tabular}

*) mean value of $n$ calculations

The detection limit determined according to KAISER (12) was $0.13 \mathrm{mmol} / 1$; the range of extreme values was $0.000-0.002$ absorbance units.

\section{Accuracy}

The 2-point procedure of the hexolinase method appeared to be linear between 0 and $20 \mathrm{mmol} / \mathrm{l}$ (Fig. 3). This range covers $99 \%$ of the routine and about $95 \%$ of all emergency glucose determinations performed in our hospital. 


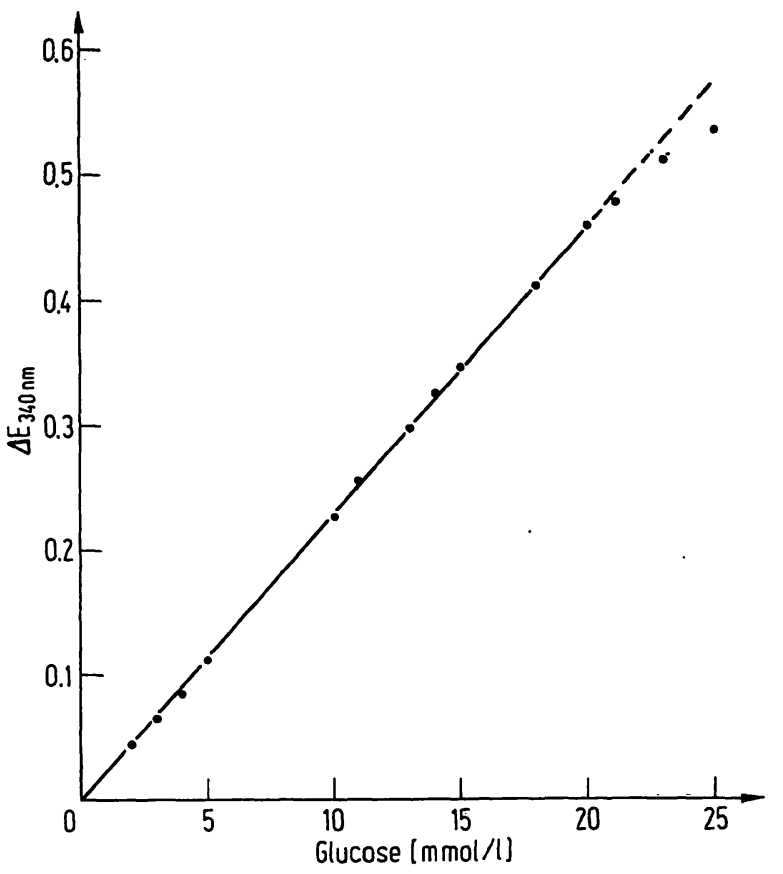

Fig. 3

Calibration curve of the two-point procedure for the determination of the glucose concentration with the GEMSAEC analyzer

Glucose was added to various serum samples. The recovery varied from $100.0 \%$ to $100.7 \%$ (Tab. 6). Furthermore, we measured the glucose concentration in capillary blood with the 2-point- and with an endpoint method. The latter included a deproteinisation step and was recently investigated in detail by us (2). The correlation between both procedures was sufficient for clinical purposes (Fig. 4).

\section{Interferences}

Recently, we have reported (2) that the glucose values are slightly higher as expected in the presence of fructose using the hexokinase method and the endpoint deter-

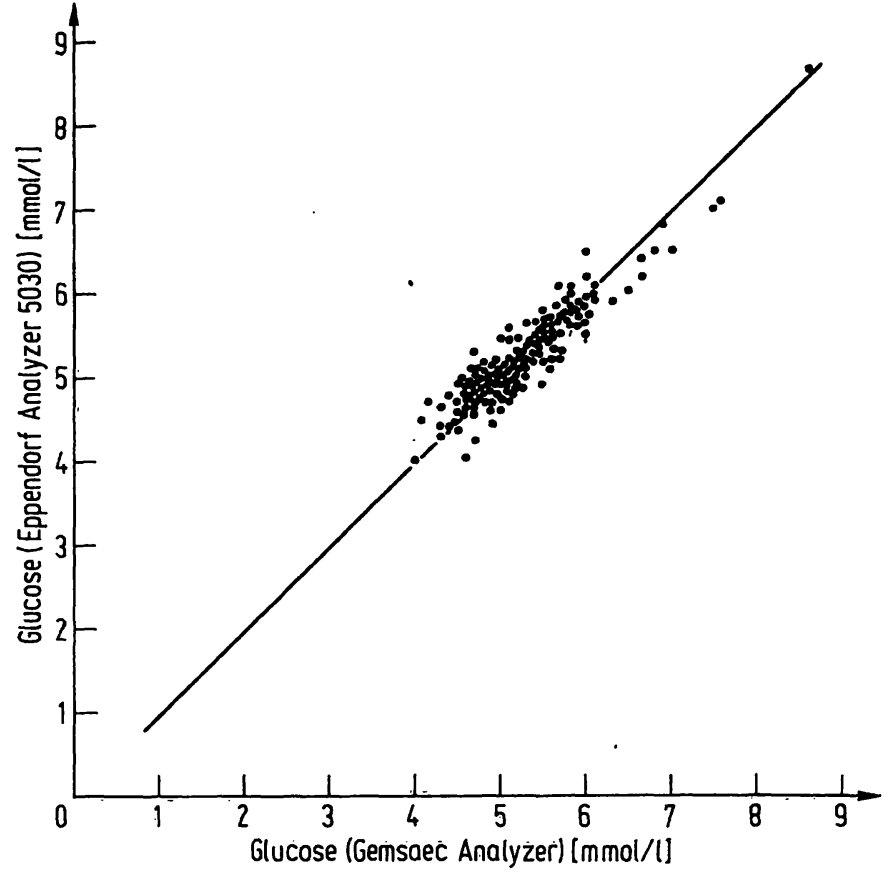

Fig. 4

Comparison of the glucose determination with the GEMSAEC (Twopoint method) and with the Eppendorf analyzer (endpoint procedure)
in capillary blood samples. Coefficient of correlation $r=0: 9957$; $y=0.9957 \times-0.0184(m=177)$

mination. This interference is avoided with the 2-point procedure (Tab. 6). Bilirubin, hemoglobin (up to $8 \mathrm{~g} / \mathrm{l}$ ) and triglycerides (up to $5 \mathrm{mmol} / \mathrm{l}$ ) do not influence the results obtained with the proposed method (Tab. 6). The only interference so far known is caused by glucose-6-phosphate, if present in concentrations above $0.2 \mathrm{mmol} / \mathrm{l}$.

\section{Interaction}

Recently we have differentiated between cyclic- and from-sample-to-sample interaction effects (11).

Interaction from-sample-to-sample was not detected

Tab. 6

Recovery of glucose added to various human serum samples and to aqueous solutions containing possible interfering substances. All values are means from at least 2 determinations

\begin{tabular}{|c|c|c|c|c|}
\hline Sample & $\begin{array}{c}\text { Glucose calculated } \\
\qquad \begin{array}{c}\left.(1+3)^{*}\right) \\
\mathrm{mmol} / \mathrm{l}\end{array}\end{array}$ & $\begin{array}{c}\text { Glucose found } \\
\left.(2)^{*}\right) \\
\mathrm{mmol} / \mathrm{l}\end{array}$ & $\begin{array}{c}\text { Recovery } \\
\%\end{array}$ & $\begin{array}{c}\text { Concentration of } \\
\text { interfering substance }\end{array}$ \\
\hline Serum 1 & 15.1 & 15.2 & 100.7 & - \\
\hline Serum 2 & 13.0 & 13.0 & 100.0 & - \\
\hline Serum 3 & 13.1 & 13.1 & 100.0 & - \\
\hline Serum 4 & 15.8 & 15.9 & 100.6 & - \\
\hline Serum 5 & 15.0 & 15.1 & 100.7 & $\ddot{-}$ \\
\hline Fructose solution & $<0.1$ & $<0.1$ & - & $20 \mathrm{mmol} / \mathrm{l}$ \\
\hline Haemoglobin solution & $<0.1$ & $<0.1$ & - & $8.6 \mathrm{~g} / \mathrm{l}^{\prime}$ \\
\hline Glucose solution + haemoglobin & 10.5 & 10.5 & 100.0 & $8.6 \mathrm{~g} / 1$ \\
\hline Glucose solution + haemoglobin & 10.3 & 10.2 & 99.0 & $4.3 \mathrm{~g} / 1$ \\
\hline Serum $6+$ bilirubin & 11.7 & 11.6 & 99.1 & $306 \mu \mathrm{mol} / 1$ \\
\hline Serum $7+$ bilirubin & 10.5 & 10.4 & 99.0 & $306 \mu \mathrm{mol} / \mathrm{I}$ \\
\hline Serum 8 (lipemic) & 17.2 & 17.3 & 100.6 & $\left.4.20 \mathrm{mmol} / 1^{* *}\right)$ \\
\hline Serum 9 (lipemic) & 14.3 & 14.2 & 99.3 & $\left.4.78 \mathrm{mmol} / 1^{* *}\right)$ \\
\hline Blood, heparinized + fructose & 4.0 & 4.0 & 100.0 & $9.5 \mathrm{mmol} / 1$ \\
\hline Glucose-6-phosphate solution & 0.1 & 4.6 & - & $\left.6.4 \mathrm{mmol} / 1^{* * *}\right)$ \\
\hline Glucose-6-phosphate solution & 0.1 & 0.4 & - & $\left.0.6 \mathrm{mmol} / 1^{* * *}\right)$ \\
\hline
\end{tabular}




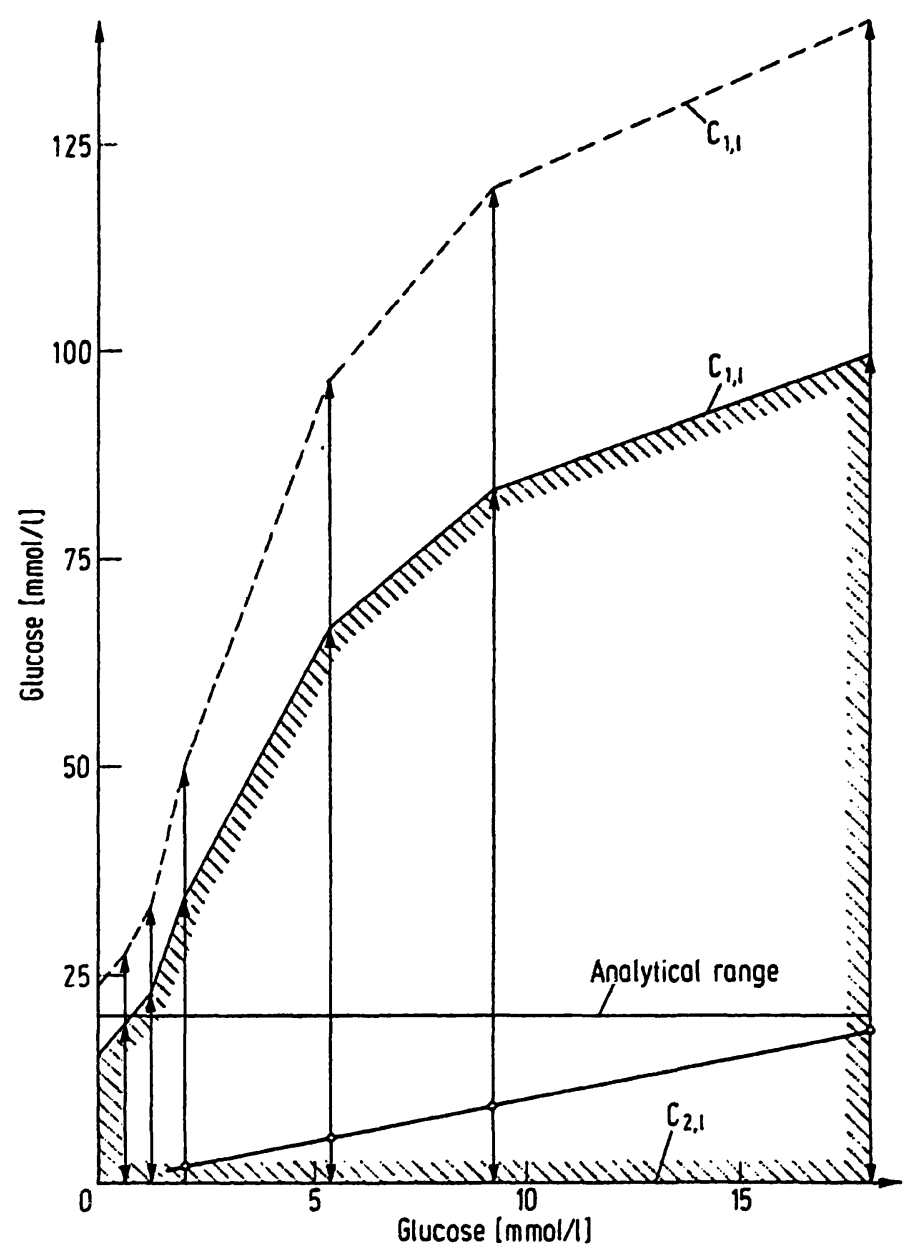

Fig. 5

The "interaction-safe range" $(10,11)$ of the glucose determination with the GEMSAEC system. The concentrations forming this range are calculated according to (10): c con for the interaction from low to high concentrations and $c_{2,1}$ for the interaction from high to low concentrations. The standard deviations are taken from Table 4 . $Q=0.3 \%(n=5)$. It is postulated that the error due to carry-over effects should be lower than the twofold (hatched area) or the threefold value of the intrabatch precision (standard deviation)

in the linear range of the 2-point procedure, from low to high, or from high to low concentrations. However, if a sample with $100 \mathrm{mmol} / \mathrm{l}$ is followed by 3 samples with $2 \mathrm{mmol} / \mathrm{l}$ glucose, a mean $Q_{2}$ value of $0.3 \%$ $(s=0.1, n=5$ ) was determined. This slight interaction effect will cause serious errors only under extreme conditions: as a rule of thumb, we suggest that all samples be reanalyzed with a glucose concentration below $2 \mathrm{mmol} / \mathrm{l}$ if the preceeding concentration exceeds $50 \mathrm{mmol} / \mathrm{l}$ (Fig. 5). This type of interaction occurs only at the Rotoloader station. If the rotor is loaded manually, carry over effects are not to be expected.

Cyclic interaction effects are encountered if the washing step is unsufficient. 2 successive runs were performed with the same rotor using various albumin solutions (Tab. 7). No significant cyclic interaction was detected with the biuret reaction.

\section{Drift}

A possible drift of the photometer and print-out system was investigated with a potassium dichromate solution $(\triangle \mathrm{A}=0.455$ at $340 \mathrm{~nm})$ : The absorbance was observed for $30 \mathrm{~min}$ and drifted about $A=0.00003 /$
Tab. 7

Investigation of cyclic interaction effects. Sample: albumin solution Indicator: biuret reaction

\begin{tabular}{ccc}
\hline Cuvette number & Albumin concentration & Print-out \\
\hline 1. Run No. $2-7$ & $20 \mathrm{~g} / 1$ & $\bar{x}=20.35(\mathrm{~s}=0.25)$ \\
$8-16$ & $250 \mathrm{~g} / 1$ & out of linear range \\
2. Run No. $2-7$ & $20 \mathrm{~g} / \mathrm{l}$ & $\left.\bar{x}=20.00(\mathrm{~s}=0.13)^{*}\right)$ \\
$8-16$ & $20 \mathrm{~g} / \mathrm{l}$ & $\left.\bar{x}=20.10(\mathrm{~s}=0.10)^{*}\right)$ \\
\hline
\end{tabular}

*) This difference is not significant: $P=0.06$ (t-test)

$\min (n=15)$. These data indicate that drift effects can be neglected if the observation is not extended over a period of $30 \mathrm{~min}$.

Time of analysis

For the 2-point procedure of the hexokinase-method each run needs its own standards and at least 1 control. Therefore, a minimal sequence contains 3 samples, which can be analyzed in $7.0 \mathrm{~min}$ excluding the blood sampling time (Tab. 8). The rotor loading requires the longest part of the total time.

Tab. 8

Time per test required for determinations of the glucose concentration with the GEMSAEC analyzer

\begin{tabular}{lcc}
\hline $\begin{array}{l}\text { Number of unknown samples } \\
\text { (including } 1 \text { standard and } \\
\text { 1 control) }\end{array}$ & 1 & 12 \\
\hline Sampling time, seconds & 30 & $13 \times 30$ \\
\hline 1. Centrifugation (1 min) & $1 \mathrm{~min} 30 \mathrm{~s}$ & $1 \mathrm{~min} 30 \mathrm{~s}$ \\
2. Rotor loading & $1 \mathrm{~min} 50 \mathrm{~s}$ & $4 \mathrm{~min} 45 \mathrm{~s}$ \\
3. Analyzer run & $3 \mathrm{~min}$ & $3 \mathrm{~min} 15 \mathrm{~s}$ \\
4. Overall time & $7 \mathrm{~min}$ & $11 \mathrm{~min}$ \\
5. Time per test & $7.0 \mathrm{~min}$ & $0.8 \mathrm{~min}$ \\
\hline
\end{tabular}

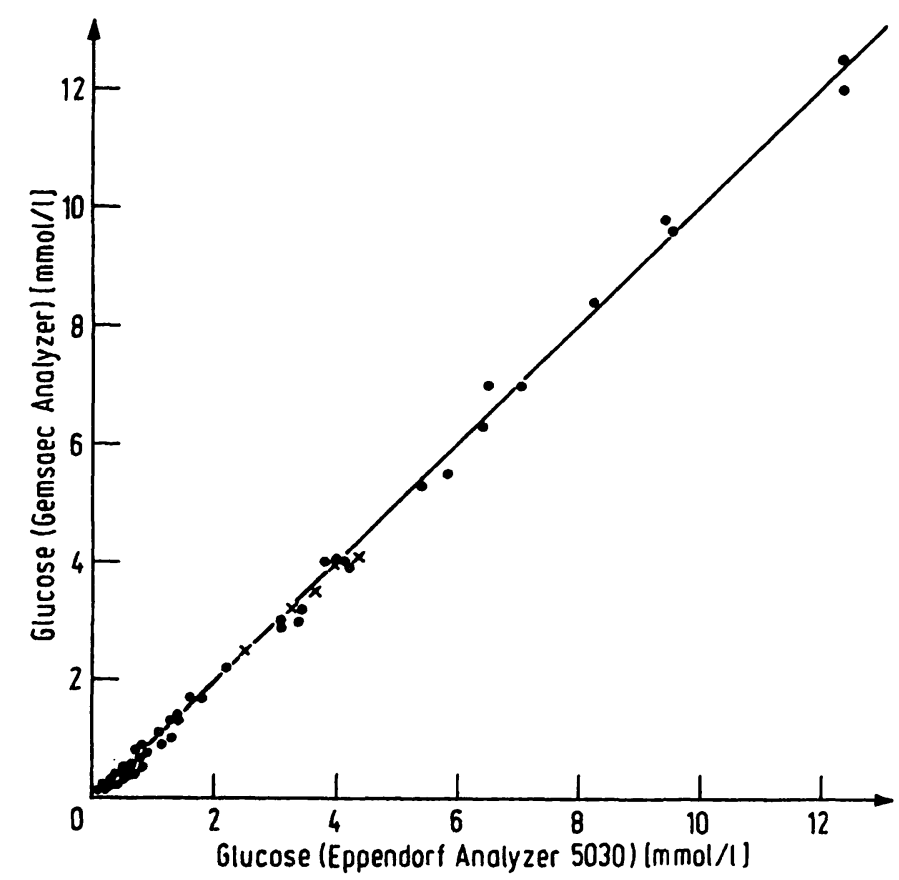

Fig. 6

Comparison of glucose values determined with the 2-point procedure (GEMSAEC) and with an endpoint procedure (Eppendorf analyzer 50.30 see 1. c. 2) of the hexokinase method in urine and cerebrospinal fluid (crosses) samples. Regression analysis: $y=1.0207 \times-0.10915$,
$r=0.9993(m=69$ pairs of data) 
Very soon, a faster loader will be introduced by the manufacturer of the GEMSAEC system. For succeeding runs a second rotor can be filled while the first is. positioned in the analyzer. This procedure saves approx. $3 \mathrm{~min}$ for the next run. Therefore about 91 samples can be processed in the first hour and thereafter 97 samples per hour.

\section{Urine samples}

Urine and cerebrospinal fluid samples were diluted with $\mathrm{NaCl}(9 \mathrm{~g} / \mathrm{l})$ containing maleimide and analyzed for their glucose concentration in the same way as capillary blood. The comparison with an endpoint procedure of the hexokinase method (2), which includes the precipitation of proteins and the determination of a blank value for urine samples, shows an acceptable correlation (Fig. 6).

\section{Discussion}

The GEMSAEC analyzer permits a 2-point procedure of the hexokinase method which is precise enough for the determination of glucose concentrations for clinical purposes. This method has 3 distinct advantages over a mechanized endpoint procedure recently described by us (2):

1. it is subject to less interference (Tab. 6), despite the fact that deproteinisation is not carried out,

2. single samples are processed more rapidly (Tab. 8), and

3. urine can be analyzed without performing a sample blank value.

A further advantage of the GEMSAEC system is that carry-over effects can almost be neglected. Whereas the analyzer itself does not contribute to the over-all interaction from sample to sample, the Rotoloader causes such an effect. However, the prerinsing device and the cleaning of the sample-pick-up tip with a small sponge keeps the sample carry-over extremely low. Determinations, which require a high precision and meet a relatively large range of extreme values, e. g. the glucose concentration in human material, should be performed with low interaction effects $(10,11)$.

The over-all kinetics of the hexokinase and glucose-6phosphate dehydrogenase reaction follow an exponential curve and will be discussed in a following report.

Acknowledgement: We are grateful to Dipl. Math. R. PIGoRs for calculating the precision data with an IBM computer 1130.

\section{References}

1. NeELey, W. E. (1972), Clin. Chem. 18, 509-515. - 2. HaeckeL, R. \& HAECKEL, H. (1972), this j. 10, 453-461. - 3. ANDERSON, N. G. (1969), Analyt. Biochem. 28, 545-562. - 4. ANDERson, N. G. (1970), Amer. J. Clin. Pathol 53, 778-785. - 5. Kelley, M. T. \& Jansen, J. M. (1971), Clin. Chem. 17, 701-706. 6. Tiffany, T. O., Jansen, J. M., Burtis, C. A., Overton, J. B. \& Scotr, C. D. (1972), Clin. Chem. 18, 829-840. - 7. Hilger, P., Henkel, E. \& Delbrück, A. (1970), this j. 8 , 579-581. - 8. HaECKel, R. (1970), this j. 8, 480-482. -9.
HJeLM, M. (1968), Z. Analyt. Chem. 243, 781-790. - 10. HAECKed, R. \& Porth, A. J. (1972), this j. 10, 91-94. - 11. HAECKEL, R. (1972), this j. 10, 235-242. - 12. KAISER, H. (1965), Z. Analyt. Chem. 209, 1-18. - 13. Maclin, E. (1971), Clin. Chem. 17, 707-714. - 14. WIDMER, G. \& BARTELS, H. (1972), Chem. Rundschau 25, 881-888. - 15, HohorșT, H. J. (1970), in H. U. Ber GMEYER, Methoden der enzymatischen Analyse, Verlag Chemie, Weinheim, 1200-1204.
Priv. Doz. Dr. R. Haeckel 3000 Hannover Karl-Wiechert-Allee 9 